\title{
The Challenges of Change
}

\section{A Review of Cataloging and Classification Literature, 2003-2004}

\author{
By Shawne D. Miksa
}

This paper reviews the enormous changes in cataloging and classification reflected in the literature of 2003 and 2004, and discusses major themes and issues. Traditional cataloging and classification tools have been revamped and new resources have emerged. Most notable themes are: the continuing influence of the Functional Requirements for Bibliographic Control (FRBR); the struggle to understand the ever-broadening concept of an "information entity"; steady developments in metadata-encoding standards; and the globalization of information systems, including multilinguistic challenges.

The overarching theme of cataloging and classification literature from 2003

1 and 2004 is one of change. A strong influence on this theme is the Functional Requirements for Bibliographic Records (FRBR), and the challenge of the digital environment and the international landscape of standards and processes. Specific change agents include reconceptualizing both what constitutes an "information entity" (IE) and how these IEs are represented within and by information systems, revisioning the standards and principles that form the core of the cataloging enterprise, and increasing globalization of systems and the ability to allow for multicultural representations of IEs. Exacerbating these changes is the persistence of obstacles (such as updating descriptive cataloging rules to include the new IEs, providing adequate quality control within bibliographic databases, and coping with constantly changing technologies) that have challenged cataloging and classification for decades. Furthermore, there is the new pressure, both within library and information science and externally, to call ourselves something other than catalogers.

\section{Research Method}

This review of the literature of 2003 and 2004 is not complete, but every attempt was made to include a significant portion of formerly published works as well as some informal works that might be considered as grey literature. Identification of the works started with the most common cataloging and classification journals. In addition to mining the author's own collection of literature, online databases were used to identify journal articles, books, or electronic resources that fell within the subject area, and either a print or electronic copy of those works were

Shawne D. Miksa (SMiksa@unt.edu) is Assistant Professor, School of Library and Information Sciences, University of North Texas, Denton. 
obtained. A bibliographic software program was used to compile the final list of 323 published items. In addition to providing abstracts for each work, subject descriptors were assigned and used as one device for sorting the collection into subcategories. Finally, major themes were identified within the collection of literature and used as a basis for constructing the review. Many works in the list are not represented in this review either because they were outside of the major identified themes or were deemed too peripheral to justify inclusion. In most cases, the decision to exclude a work was not intended as a judgment on the value of the content, but rather a matter of selectivity based on the need to write a readable article. In a few cases, the author relied on her professional opinion to determine the relevance of some works. Alternatively, something may simply have been overlooked. Reviewed works range from conference proceedings, books, and other monographs to print- and electronic-journal articles and electronic resources, in general. The broad categories into which the works are placed provide some measure of orientation, but may fail to fully represent works that span several categories.

\section{FRBRization-The Influence of FRBR}

Introduced in 1998, FRBR is now settling down into the minds of information organizers everywhere. The traditional catalog is dependant upon redundancy of information within the record and traditional processes of quality control. FRBR is intended to reduce the redundancy and bring together more efficiently records that describe one entity, both for the benefit of the user and the cataloger. Numerous articles have addressed how to implement FRBR, described case studies of the FRBR implementation, and speculated on future concerns and issues associated with the impact of FRBR. This section highlights some of the many articles that have been published and touches on the major themes emphasized by the authors.

\section{Bibliographic Principles and General Works}

The first International Federation of Library Association (IFLA) Meeting of Experts on an International Cataloging Code was held in Germany at the IFLA 2003 annual conference. This meeting of experts resulted in the "Statement of International Cataloging Principles," a re-envisioning of the "Paris Principles" established in 1961 at the International Conference on Cataloging Principles in Paris, France. ${ }^{1}$ This new statement is now commonly referred to as the "Berlin Principles" and incorporates the new conceptual models detailed in FRBR and Functional Requirements and Numbering for Authority Records (FRANAR). ${ }^{2}$ Comparing the two principles side by side reveals the change in direc- tion and terminology. The 2003 version takes a broader look at information entities within the context of information systems and user searching needs by incorporating the FRBR conceptual model and the four user tasks of finding, identifying, selecting, acquiring or obtaining. ${ }^{3}$ Svenonius had suggested adding navigation as a fifth task in $2000 .{ }^{4}$ To the delight of catalogers worldwide, the draft addresses the range of information resources found in the current information environment and seeks to broaden the discussion to include all aspects of bibliographic and authority records. The Berlin Principles represents the renewal of an effort to bring standardization to information systems worldwide. ${ }^{5}$

Storey gives a brief overview of experiments from 2001 designed to examine the implications of FRBR and the practical difficulties in implementing its approach; He states that implementing FRBR may not be as cumbersome as first thought and could potentially "reduce the cost and increase the quality of both original and copy cataloging." Statistical estimates on impact are provided based on the results of a test of the conversion tool on 1,000 WorldCat records. Because a manual changeover of databases to the FRBR model would be too costly, OCLC is offering a free algorithm to any organization interested in converting their records to the model. ${ }^{7}$ Tillett, as well, gives an overview of FRBR, emphasizing in particular the impact it will have on cataloging rules and bibliographic structures. ${ }^{\mathrm{s}}$

Taniguchi has investigated creating MARC records from preexisting records based on the conceptual model given in FRBR (i.e., taking what FRBR defines as "the key objects of interest to users of bibliographic data") in which the "expression-level" entity is given primacy. ${ }^{9} \mathrm{He}$ compares FRBR with different conceptual models in order to examine differences in modeling component parts of bibliographic resources and to clarify if entities at the component level can operate in the same way as entities at the integral unit level. ${ }^{10}$ His work on developing a conceptual model of the cataloging process, which has never been attempted, has been in response to the focus on the user's needs in the model outlined in FRBR. ${ }^{11}$

Antelman investigates "work identifiers" for serials because she believes that less attention has been paid to the development of a conception of a serial work. ${ }^{12}$ She states that "mechanisms that control the work of monographsthe main entry heading and uniform title-are weak identifiers for serials" and that a higher level of abstraction is needed, such as the abstract layers "work and expression" within the FRBR model..$^{13}$ Antelman gives an example of a serial work within the FRBR model in which she creates different expressions of a journal by using an aggregatorneutral record outlined by the Cooperative Online Serials (CONSER) program. Potentially, the user would see "the work once and display relationships between manifestations as well as associated holdings and other qualitative attri- 
butes." 14 Antelman's exploration of different models and the Notes at the end of her article are a good source for further reading.

Other articles explore the concept of a "work" in online databases such as WorldCat, the concept of a "record," and the need to develop the FRBR model within the context of an actual library catalog system in order to see how the record itself would be restructured. ${ }^{15}$ However, there are still issues with the current cataloging practice that need to be addressed. For example, Guerrini explores the history, scope, and functional role of the General Material Designation (GMD), and the need for a sound definition of a "mode of expression" as it relates to the use of GMD in bibliographic records. ${ }^{16}$ Oliver reports on the long-standing issue of format variations, and states that the work of the JSC Format Variation Working Group has been influenced by the FRBR model and is linked to the format variation problem. ${ }^{17}$

Riva addresses the issue of how user record retrieval is affected by taking on the bidirectional mapping of MARC 21 linking entry fields to the FRBR and Tillett/Smiraglia theoretical breakdowns of bibliographic relationships. ${ }^{18}$ The mapping demonstrates that "all linking fields are not alike, and that users may not be well served by functionality that retrieves a complete set of linked records in an entirely undifferentiated fashion." ${ }^{.19}$ At the same time, there is enthusiasm about the possibilities hinted at by FRBR. Chapman and Danskin view FRBR as a way to "overthrow the tyranny of the catalogue card by creating a new paradigm in which the strengths of information technology to access and link data are exploited rather than constrained." However, the authors caution that there is not yet sufficient data of FRBR's efficiency.

Lastly, the Association for Library Collections and Technical Services (ALCTS) division of the American Library Association (ALA) sponsored numerous presentations at the 2003 and 2004 Annual Conferences that focused on topics such as FRBR in general and, more narrowly, FRBR's application to continuing resources (AACR2, chapter 12), subject references, metadata harvesting, preservation, approval plans, implementation and documentation of UNICODE for catalog access, serials standards, and e-books. ${ }^{21}$

\section{Projects and Case Studies}

With the efficiency and effectiveness of FRBR still in question, the next natural step was to test its data model. Hegna and Murtomaa set out to analyze a MARC record in order to answer two important questions-whether one can find the FRBR structure in the existing MARC records and, if so, how one can use this structure in the catalog's user interface. ${ }^{22}$ The answer they found to the first question was both "yes" and "no," especially when looking at only one record. Examining a set of MARC records produced roughly the same results-some structure was found, but it was not entirely matched to the FRBR model. Attempts to exploit the structure for a user interface met with some success, but the authors found that certain characteristics of the MARC fields ( e.g., function in the 700 field, how original titles are entered, language codes) interfered with how the information was displayed to the user.

Another case study revolved around the Australian Literature Gateway (AustLit), a resource service for writers and writing, in which the FRBR model was augmented with event modeling. ${ }^{23}$ This project also incorporated the concept of a "SuperWork" - a combination of variations of a work that may be in different embodiments (e.g., a book as well as an opera). Event modeling allowed for expanding three of the four FRBR concepts—work, expression, manifestation:

- works have a creation event;

- expressions have a realization event; and

- manifestations have an embodiment event.

Ayres and company describe in detail the stages and outcomes of the project and demonstrate that it was possible to "implement the model and many of the extensions which FRBR commentators have suggested . . . to reorient and retrain professional staff within the system, and to develop a user interface which hides the complexities of the model, while presenting meaningful context information to users." ${ }^{24}$

Chen and Chen present a case study of the National Palace Museum (NPM) in Taipei in which the FRBR model is used to identify the proper organization of metadata elements and their distribution over FRBR entities within a more media-centric and association-rich contents. ${ }^{25}$ Because this is a museum, two different metadata strands are needed. First, researchers need intellectual content without necessarily specifying various formats. Alternatively, managers need format information for management responsibilities. One of the initial findings Chen and Chen discovered was that the application of the model was beneficial because it resulted in a "distribution of metadata elements that focuses on intellectual content" as the "work and expression are two focal entities of the metadata requirements and proves to be especially suited for projects dealing with the research of Chinese paintings and calligraphy."26 The complete results are covered in this report, as well as reviews of other FRBR projects and their outcomes. 


\section{Metadata Encoding Standards: Their Evolution and Relationship to MARC}

At the 2004 annual IFLA conference, the Cataloging Coordinating Board sponsored a session on "Developments in Cataloging Guidelines," at which the Berlin Principles drafted the previous year were discussed. Howarth reported on the work of the IFLA Cataloging Section Working Group on the Use of Metadata Schemas and the responses received on the three objectives that formed the Working Group's terms of reference. ${ }^{27}$

Howarth ended this presentation by asking about what core records for resource discovery should contain and how that data should be created, derived, or exchanged. She posited that when "satisfactorily addressed, then issues related to standards development and maintenance, to automatic extraction [and] ... generation of appropriate metadata, and to cross-schema interchange (crosswalks; interoperability) will have a proper context, some common ground, and an obvious raison d'être."28 This paper exemplifies the issues facing the cataloging and classification community, which finds itself challenged by an increasing array of questions pertaining to metadata interoperatibility and crosswalks.

\section{The XML and MARC Debate}

Abrams views Extensible Markup Language (XML) as the "centerpiece of most developers' bets on the future." ${ }^{29} \mathrm{In}$ his short piece for the "Information Trends" column in Information Outlook, he outlines new technologies that may be helpful to the future of organization of recorded knowledge. XML, he writes, "allows us to tag information beyond traditional fielding but without the hard edge of avoiding delivery or user context." ${ }^{30}$ In particular, XML would enable more user-centric coding by allowing organizers to set display variables based on a user's skill level, by sensing the user's device in order to adapt to their context, and by sharing content-tagging definitions across types of systems. McCallum, who points out that XML is grounded in work of at least twenty years - starting with the ISO standard for the Standard Generalized Markup Language (SGML) — discusses the Metadata Object Description Schema (MODS). ${ }^{31}$ This schema is a derivative of MARC 21 specifically designed to let catalogers take advantage of MARC21 within an XML environment.

Andresen contends that XML-encoded library data are a mainstream technology, and that XML is more in line with FRBR concepts and as such "related works can be linked (on the basis of the FRBR concept) and relationships presented in a logical way to the user."33 MARC, oriented toward the 1961 Paris Principles, focuses on the description of individual documents making it "difficult to handle relations between data that are described in different fields." ${ }^{34}$
Andresen's comparison of MARC with XML, as well as with the Danish MARC format danMarc2, raises the question of how to create descriptions with several layers, which can be used in various contexts and still have minimum data duplication. Similarly, Tennant proposes a new metadata infrastructure in which XML is the most reasonable solution as a transfer schema. ${ }^{35} \mathrm{He}$ reports on the efforts of OCLC and Research Library Group (RLG) to change their respective bibliographic databases into XML-based systems. OCLC's WorldCat database now has an "internal XML metadata schema devised by OCLC to accept nearly any type of metadata." ${ }^{36}$ Wusteman, on the other hand, warns of complicated patent-related issues, linked to companies such as Microsoft, that may result in millions of unreadable documents. ${ }^{37}$ She cautions that archiving documents in formats encumbered by patents will always be a bad idea.

Carvalho et al. look at meta-information, the information about the standard that they view as central for the validation of bibliographic records. ${ }^{38}$ A MetaMARC Schema is proposed using an XML framework, with the idea that it will lower implementation costs, facilitate the standard use of XML in bibliographic records, and "extend the authoritative function and reach of the documentation produced by the MARC standard agencies."39

The Library of Congress (LC) has begun developing an XML environment for working with MARC data that will allow for specific uses of the data. Design considerations such as flexibility, loss-less conversion of MARC to XML, "Roundtripability" from XML back to MARC, editing, validation, and extensibility are among the issues being discussed. ${ }^{40}$ Version 1.1 of the schema and an illustration of it can be found on the LC MARC Web site. ${ }^{41}$ That architecture, and specific uses and features of the schema are illustrated and discussed, and examples are provided.

The LC Web site also has a Java-based MARCXML Toolkit that allows for conversion between XML and MARC file formats. ${ }^{42}$ Keith's overview of the schema architecture includes a tutorial as well as a discussion about different applications and tools of the Toolkit. ${ }^{43}$ This overview is intended to standardize an approach to MARC metadata in XML and to provoke thought on additional uses of that architecture.

The call for increased focus on XML also appears in several books. Miller and Clarke's Putting XML to Work in the Library offers tools for incorporating XML within traditional information organization and control activities. ${ }^{44}$ The authors stress the importance of XML to information management in libraries with the hope of spurring the construction of more flexible and sophisticated systems. The text contains simple tools and explanations for a variety of XML uses. Caplan also touches upon XML within the broader arena of metadata applications in her 2003 Metadata Fundamentals for All Librarians as does Haynes 
in his 2004 book Metadata for Information Management and Retrieval. ${ }^{45}$ Many of the articles previously discussed come from two special issues of Library-Hi Tech, which address case studies, experiments, and opinions on the MARC format and, as a whole, approach the question of whether or not MARC will still be viable in the future. ${ }^{46}$

The MARC standard has been the subject of intense speculation over the past few years. Many papers discuss it in terms of advancements in its use for the control of new electronic resources; some compare it (as shown above) with other encoding standards and methods, while others discuss it in terms of its possible demise. Gorman calls MARC a historic achievement that made universal bibliographic control possible. ${ }^{47}$ He reminds us that:

It should be unnecessary to point out that MARC is merely a framework standard - that is, it is a way of storing and making data capable of manipulation that has been formulated in accordance with content standards (cataloguing codes and the like). I would not trouble to point that out were it not for the frequent references to "MARC cataloguing" in writings about metadata and "simplified" cataloguing. There is, of course, no such thing as "MARC cataloguing"-MARC is the way we encode the results of the cataloguing process and has little or no influence on that process. ${ }^{48}$

However, some authors believe MARC is truly inflexible and that the cataloging community should not focus on what could have been done with it under different circumstances. ${ }^{49}$ Tennant sees sole reliance on MARC—despite the millions of resources cataloged using non-MARC encoding - as detrimental, and warns us to "ignore these [nonMARC] resources at our peril." ${ }^{.50}$ Some take a more structured approach to the reliability and sustainability of MARC. Yee chooses to explore problems associated with the MARC 21 format and then place the problems into four categories-(1) problems that are not the fault of MARC, (2) problems identified that perhaps are not problems, (3) problems connected with the current shared cataloging environment, and (4) problems either caused or partially caused by MARC 21 and that could be solved in the process of migrating data to a future data-structure standard ${ }^{51}$ Yee has closely studied the cataloging literature (her reference list is a solid source for other researchers) and identifies misperceptions about MARC made by other writers (e.g., pointing out the mistaken notion that XML is superior to MARC 21 in its degree of hierarchy) and factual errors in research (e.g., clear misunderstandings about the function of various MARC fields). She offers recommendations for resolutions of specific problems within the third and fourth categories and warns catalogers to "be careful not to destroy what we have in a rush to emulate the rest of the world, which may be on the threshold of recognizing its own need to develop solutions similar to the ones we in the library world already employ."52

\section{Projects and Case Studies}

Several interesting studies using the MARC 21 format have been published. Carini and Shepard report on the Mount Holyoke College Archives and the Five College Finding Aids Access Project in which the format is discussed in relation to the Encoded Archival Description (EAD). The authors aim to demonstrate that greater standardization in archival description allows archivists to respond more effectively to technological change. ${ }^{53}$ Davis explores standardization efforts by archivists beginning in the late 1970s, including the development of the MARC AMC format. ${ }^{54}$ Wisser and Roper report on North Carolina State University's implementation of EAD and discuss the commonalities between creating descriptive metadata schemas; it is enhanced by project members' varying objectives. ${ }^{55}$

Cyril, a program to add Russian characters to existing MARC records, has been examined for any multilingual or multiscript implications it might have for cataloging and authority-control standards. ${ }^{56}$ The results of the study demonstrate that MARC inflexibility is actually beneficial for Cyril's success. Similarly, the use of USMARC for cataloging mathematical and scientific curriculum materials at the Eisenhower National Clearinghouse (ENC) is examined, including issues related to cataloging interface integration. ${ }^{57}$ Surratt and Hill report on the creation of MARC records for electronic theses and dissertations (ETD) using a Perl script to extract metadata from an ETD database and the cataloging workflow issues associated with it. ${ }^{58}$ Jul notes the disconnect between information organization and access in libraries and nonlibrary organizations. He argues that the library community needs to provide instructions that will make metadata usable, meaningful, and retrievable, particularly when it pertains to the nonlibrary community. ${ }^{59}$ Lastly, as an example of large numbers of projects involving metadata development, Hunter's review of the metadata research efforts for organizing information resources on the Web demonstrates that metadata efforts are far from trivial and very valuable, despite the difficulties. ${ }^{60}$

\section{Cataloging Tools and Resources AACR2}

The Anglo-American Cataloguing Rules, 2nd edition, revised (AACR2), was updated in both 2003 and $2004 .{ }^{61}$ Changes to the rules in the 2003 update included new definitions for the terms "Cartographic materials," "Globe," and "Map," as 
well as changes to rules in chapters $12,21,24,25$, and $26 .{ }^{62}$ The 2004 update included notable changes to chapter 9 , specifically the removal of the material specific details area. This area is no longer used for electronic resources. Chapter 1 , rule 1.0A "has been lengthened, including a new subrule, $1.0 \mathrm{~A} 3$, to explain more fully the concept of 'chief source of information." "63 In addition, catalogers can now include more flexible descriptions of the physical carriers of sound recordings (rule 6.5B1), videorecordings (rule 7.5B1), and electronic resources (rule 9.5). Catalogers have the "option to record a physical description of a remotely available electronic resource, instructing that the term used come either from an appropriate subrule .5B (from one of the chapters in AACR2 Part I) or from common usage. ${ }^{.64} \mathrm{~A}$ list of these changes can also be found on the Joint Steering Committee for the Revision of the Anglo American Cataloguing Rules Web site. ${ }^{65}$

\section{General Cataloging Texts}

The release of the 2002 edition of AACR2 and its subsequent updates has reverberated into new and revised general cataloging works and textbooks in 2003 and 2004. Fritz released a revised version of Cataloging with AACR2 and MARC 21 that includes changes through to the 2004 AACR2 update. ${ }^{66}$ This volume remains one of the more comprehensive works on the marriage between AACR2, MARC, and other tools, and is particularly useful when teaching descriptive cataloging. Fritz introduces the relationship between AACR2 and MARC before proceeding to the cataloging process as a whole, in which catalogers must learn to navigate and interpret rules to generate metadata for use in an electronic catalog record. She eloquently states that, while the manual "cannot claim to be a completely comprehensive tool," it can show the "many patterns in the web of information that we have been trying to weave into coherence long before the days of www. This work is an attempt to reveal some of those wonderful patterns to those of us who enjoy this kind of thing." ${ }^{\circ 67}$ Her particular approach brings together AACR2, LC Rule Interpretations, MARC, LC Classification (LCC), Dewey Decimal Classification (DDC), OCLC, subject headings, general cataloging works, and a healthy supply of her own "Hints" to guide catalogers through the cataloging process. One last comforting aspect of this work is the author's complete understanding of the fear an empty MARC record causes the uninitiated cataloger. Fritz and co-author Richard Fritz have also published MARC21 for Everyone: A Practical Guide, which focuses exclusively on MARC21 and is aimed at the beginning cataloger. ${ }^{68}$

Another familiar handbook is Maxwell's Handbook for AACR2, revised, which includes changes up through the 2003 AACR2 update. Major revisions include chapter 3, chapter 9 , and chapter 12 , as well as incorporating the new concept of "integrated resources" and all significant changes of the MARC format. ${ }^{69}$ Maxwell stresses that this edition follows "the basic premises of the first edition," but cautions readers not to use the book as a substitute for a proper "self-help manual." ${ }^{\text {"70 }}$ Maxwell offers detailed explanations for cataloging problems, citing each rule in full and providing examples of title pages and sample MARC records for easy reference.

The release of the ninth revised edition of Wynar's Introduction to Cataloging and Classification also coincided with the release of the 2002 edition of AACR2. The text, by Taylor, incorporates the 2003 AACR2 update and takes into account the change from "computer files" to "electronic resources" and the derivation of the chief source of information from Web sites, the change from "serials" to "continuing resources," and the new concept of "integrating resources." ${ }^{\prime 11}$ Moreover, new examples have been added, and MARC examples have been changed to reflect MARC21. Taylor also briefly discusses FRBR and its incorporation into the expected AACR3, to be renamed Resource Description and Access (RDA).

A new cataloging text is Bowman's Essential Cataloguing. ${ }^{72}$ Unlike the usual cataloging texts, such as those previously discussed, it does not devote one chapter each to the different formats as outlined in AACR2 Chapters 2-12. The author asserts that anyone who understand the principles of cataloging should be able to transfer them to all kinds of materials. Therefore, chapters are devoted to fundamentals of descriptive cataloging by covering the eight areas as outlined in the International Standard Bibliographic Description (ISBD) and AACR2 chapter 1. Subsequent chapters address access points (covering much of part II of AACR2), multipart works, headings for persons and corporate bodies, authority control, and uniform titles. Title pages are reproduced in most chapters and an appendix provides MARC records for the examples used throughout the book. Bowman also reminds his readers of the continuing need for cataloging, even though it is unpopular and "nowadays little taught," and that computers still cannot completely replace catalogers.$^{73}$ He illustrates this by logically pointing out all the ways in which catalogers are needed now more than ever.

Read's Cataloguing Without Tears is a general text on descriptive and subject cataloging for the beginning library and information science (LIS) professional. ${ }^{74}$ The author divides the book into two parts: the big picture and the nitty gritty, and makes no assertion that by reading her work one would learn cataloging. Instead, she covers peripheral issues such as cataloging policies, choosing a records-management system, staffing concerns, and broadly discusses the more difficult subjects such as distinguishing among formats, dealing with unknown languages, and authority control. She states the "very best way to learn is to catalog a wide variety 
of different materials with an experienced cataloger at your elbow telling you what to do next (and why)...[or] you will have to sit down with the cataloguing guidelines for your organization, put an icepack on your head and try to work it out for yourself., ${ }^{, 75}$

\section{Cartographic Cataloging Texts}

Cartographic Materials: A Manual of Interpretation for AACR2, 2002 Revision, second edition, was published in 2003 after a series of revisions of corresponding works, which is described in the preface of the second edition. ${ }^{76}$ This new edition has taken into consideration the "changes and developments in cataloguing cartographic materials since the publication of the first edition" and how "the introduction of geographic information systems (GIS) and digital geospatial data has dramatically changed the field of map librarianship." 77 An update to this newly revised classic text was released in $2004 .^{78}$

Andrew's Cataloging Sheet Maps: The Basics received many favorable reviews and, like Fritz's work, grew out of several years of workshops. ${ }^{79}$ By focusing exclusively on sheet maps, Andrew is able to devote whole chapters to specific areas of descriptions and the corresponding encoded fields (e.g., mathematical data area, notes). The author includes what he describes as "a necessary dose of cataloger's judgment," believing in flexibility "within the bounds of the rules that we use, as well as in applying common sense where needed." ${ }^{\prime 0}$ Lastly, sections four and five of the book address subject analysis and classification using the G-schedule of LCC and historical maps and special cases.

\section{Electronic Resources Cataloging Compilations}

A compilation on cataloging of electronic serials and monographs, released in 2003, includes papers by twelve authors grouped into three areas: introductory papers that explore the larger topical area of libraries and metadata, the employment of metadata in libraries, and specific instances of libraries dealing with AACR2 and metadata standards. The intention of the book is to "explain, describe, and illustrate the brave new world libraries are creating through the use of metadata." ${ }^{\$ 1}$ Notable authors include Gorman, Baca, Tillett, and Romano Reynolds.

Another collection includes three chapters by different authors focusing specifically on cataloging e-resources and metadata. In this updated edition of a 1998 publication, Shadle examines AACR2 rules and points out that the flaws of the cataloging code, which was developed for a different information environment, are becoming more obvious. ${ }^{82}$ He also examines current problems such as identifying first issues, chief sources of information, mutability, and multiple versions, and discusses some of the solutions being developed. Cole addresses the selection of the chief source of information for electronic serials, contending that AACR2 rule revisions help with cataloging print serials, but are still ambiguous for electronic serials. ${ }^{83}$ He believes CONSER documentation is more helpful on this issue. Wool addresses metadata in order to demystify metadata by demonstrating that cataloging and metadata collection are, essentially, the same. ${ }^{84}$

Coleman's work on the selection and cataloging of Web resources focuses on "the information research process that takes place among lower division college students ... to help you understand educational needs, the types of information resources that can meet these needs, and how to enhance the library catalog with electronic information resources." ${ }^{\$ 5}$ Two unique features of this book are the manual in part II for cataloging with Dublin Core elements and education elements from IEEE Learning Object Metadata (LOM) and the worksheets in part IV to be used for "selecting resources, creating metadata, and doing a quality assurance check with a subject expert." 86

The North American Serials Interest Group (NASIG) published the proceedings of its 2002 and 2003 annual conferences both as book compilations and simultaneously as volumes 44 and 46 of The Serials Librarian. ${ }^{87}$ The 2002 conference "Transforming Serials: The Revolution Continues," focused on cataloging e-serials. One preconference gave a detailed discussion on the specific MARC 21 tags used for cataloging electronic serials and included hands-on exercises for the audience. Other presentations addressed cataloging serials reproductions, the role of catalogers in the creation of the K-State Digital Library, cataloging for consortiums, AACR2 rule revisions of chapter 9 and chapter 12 , and e-journal access at the University of Tennessee. The 2003 conference included a pre-conference on cataloging survival techniques for the non-cataloger. Session topics and workshops contained presentations on the serial work in the California Digital Library Catalog, consideration of opportunities springing from the changing role of a cataloger to an ontologist, and a case study of using MARC records for electronic resource management at Auburn University. ${ }^{88}$

\section{Music-Cataloging Texts}

Cataloging music and sound recordings has also been addressed, most recently in the 2004 book Cataloger's Judgment: Music Cataloging Questions and Answers from the Music OCLC Users Group Newsletter. ${ }^{89}$ The content comes directly from Weitz's "Q\&A" column in the newsletter going back to 1989 . The title was deliberately chosen because:

it emphasizes that real-world instances, in spite of our never-ending efforts to codify practices, will always defy those efforts. The world of stuff to catalog is so vast, so slippery, so surprising, that 
individual judgment will always enter into our decisions. And it suggests that catalogers are not the mindless drudges that many non-catalogers imagine, but instead are thoughtful judges concerning matters of description and access. ${ }^{90}$

Weitz has arranged the chapters to address major categories of questions: main and added entries, titles, description and related fields, notes, subject access, numbers, and fixed fields. Rule revisions, MARC fields, and the like are addressed as well, although Weitz cautions that, in the interest of minimizing changes to the original questions and answers, "there are countless references to outmoded technologies; superseded documentation and page numbers, old forms of headings, dead URLs; bibliographic and authority records that have long since changed; ancient rules; and obsolete practices." ${ }^{\text {91 }}$ Weitz does not use illustrations and example records, but readers can follow the discussions by accessing the OCLC records for items under question.

An interesting dissertation published in 2004 is Gardinier's work entitled Access Points Perceived as Useful in Searching for Music Scores and Recordings, in which she employs a qualitative study on access-point retrieval for music scores and recordings to try to characterize the cultural environment that may affect choice of and access to these materials. ${ }^{92}$ This is noteworthy research because it presents information about access points from the perspective of the musician.

\section{Major Classification Schemes and Controlled Vocabularies}

The 2003 edition 22 of DDC "reflects current thought in knowledge organization and incorporates updates and changes identified during the life of Edition 21." ${ }^{" 93}$ The abridged $D D C, 14$ th edition, was published the following year. ${ }^{94}$ One interesting change in DDC22 is the shortening of the manual notes. Additionally, the Editorial Policy Committee (EPC) has striven to take a more international stance in order to remain relevant and useful. EPC is quick to point out that DDC22 is the first edition to be "produced in the context of the web environment," which has enabled continuous updates and provision of those updates to its users. ${ }^{95}$ One of the major changes to the system has been the removal of table 7 (Group of Persons). Other changes can be read in the "New Features in Edition 22" section of the first volume. ${ }^{96}$

Mitchell and Chan have a newly updated textbook to accompanying DDC22. ${ }^{97}$ It covers all the important points a novice needs to learn about DDC by devoting chapters to the subject-analysis process, how to use the manual, relative index, practical number building, standard subdivisions, geographic issues, use of specific tables, as well as including number building for complex subjects, a glossary, and an extensive bibliography. Each chapter includes exercises with answers provided in an appendix.

The changes to DDC have not entirely placated everyone in the LIS community. Kua asserts that there is still a bias in DDC because it is still based on a nineteenth-century North American academic environment and shows a bias no longer acceptable for libraries in the twenty-first century. ${ }^{98}$ Kua urges national libraries to address the issue, and to investigate new models for adapting DDC. However, EPC contends that it does recognize the diversity of its users and has worked toward removing Christian and western bias from the classification. ${ }^{99}$

LCC issued several revised schedules during 2003 and 2004. A quick review of the LC Cataloging Distribution Service Web site shows the following schedules were published in 2004: KB Religious Law, KF Law of the United States, PN Literature (General), PQ French, Italian, Spanish, and Portuguese Literatures, P-PZ Tables Language and Literature Tables, and Q Science. ${ }^{100}$

The Universal Decimal Classification Consortium has announced that the latest edition of the Universal Decimal Classification (UDC) will be published in 2005. In the meantime, official changes can be read in Extensions and Corrections to the UDC, a serial publication from the Consortium. ${ }^{101}$ Revisions and proposals are given in this publication, as well as communications, and articles about the system. A reprint of Slavic's paper from the 2003 IFLA conference addresses the implementation of synthetic classification systems, such as UDC, in information-retrieval systems and "summarizes the most important functionalities of the UDC that need to be taken into account" so as to serve as an "underlying knowledge structure that provides systematic subject organisation and thus complements the search using natural language terms." 102

Classification in general is also addressed in another compilation of articles entitled Knowledge Organization and Classification in International Information Retrieval. ${ }^{103}$ This collection of articles includes topics such as adapting classifications across languages and cultures, specificity and UDC, classification of international economic data, and classification and the Web.

Several of the primary tools for providing subject-heading access have been updated. Publications in 2003 and 2004 included edition 18 of Sears Subject Headings, editions 26 and 27 of the Library of Congress Subject Headings, editions 15 and 16 of the Free-Floating Subdivisions, and the cumulative edition 5 of the Subject Cataloging Manual: Subject Headings with all updates through $2004 .^{104}$

Broughton published a new textbook, entitled Essential Classification, in 2004. ${ }^{105}$ The author states in her introduction that "emphasis throughout is on the activity of classification rather than the theory, the practical problems of 
the organization of collections, and the needs of users."106 Unlike classification texts devoted to one particular system, this work approaches classification more broadly and examines underlying principles first before moving on to different structures and techniques for classifying. Each chapter includes examples and exercises with answers (but without explanations). A glossary and categorized bibliography are included.

\section{Historical Works}

Another compilation of works coming from articles originally published in Cataloging \& Classification Quarterly (CCQ) in 2002 and 2003 is Historical Aspects of Cataloging and Classification. ${ }^{107}$ The participating authors cover an extensive range of topics within a variety of international settings. Spanhoff's analysis of the fundamental principles underlying AACR is interesting, especially in light of the newly drafted Berlin Principles as discussed earlier in this paper. ${ }^{108}$ She expresses concern with the direction being taken (at the time) by the Joint Steering Committee for the Revision of AACR, which sought to revise the fundamental principles underlying AACR by using FRBR. Spanhoff writes that FRBR does not deal with catalog structures and records as defined in AACR. Her article was chosen as the best article for volume 36 of $C C Q$ for her "ability to combine a historical analysis of cataloging principles with commentary on how the various theoreticians and standardsetting bodies are working on creating new principles for the online environment."109

Two additional papers of note are Bradley's overview of music classifying and cataloging in American libraries and Guthrie's look at the influence of medieval monastic library classification on modern schemes, in particular class $\mathrm{B}$ of the LCC system. ${ }^{110}$ The last paper in the volume is a history of "the work" in modern catalogs by Smiraglia, in which he asserts that a work is more than simply the creative activity of an individual. ${ }^{111}$ Instead, it is the product of intellectual activity spread across time and culture. $\mathrm{He}$ goes on to observe that the modern catalog has failed to impose a universal order on the elusive work-phenomenon. Smiraglia's focus on this classic concept is timely as it is one of the essential components of FRBR.

\section{Library Classification}

Several investigations focused on the effectiveness and unique uses of classification systems in a variety of information environments, as well as theoretical and historical issues surrounding the overall use of the systems.

Mai examines the future of classification as it relates to subject interoperability and the use of both general and specialized classification schemas. ${ }^{112}$ In particular, he recom- mends that "international exchange of bibliographic records and interoperability across information retrieval systems will be possible if general classification systems are used in conjunction with special indexing systems." 113 The broad organization combined with the specialized systems will allow for domain specializations that could enable users to find information more easily.

Zhao conducted an interesting study to identify problems with assigning Cutter numbers within LCC, and identifies three major problems with number assignment-Cutter numbers assigned not following the LC Cutter Table, confusion when using the Cutter Table, and problems caused by the first few letters in the first work or first word(s) of main entries being the same. ${ }^{114}$ Frank and Paynter investigated the automated assignment of classification numbers using LCC in the INFOMINE virtual library. ${ }^{115}$ In essence, they trained a "hierarchical classifier" to assign LCC numbers using approximately 850,000 records by using mappings of LC subject headings to LC classification numbers.

Araghi examines the relationship between classification and information retrieval (IR) within current information systems. ${ }^{116}$ He writes that they are so intertwined that they cannot be separated-but if they could be separated, it would reveal that better effort in classification and indexing results in better retrieval. In another article, he proposes a new classification system called the Universal Binary Classification (UBC) that would be used for book classification and indexing. ${ }^{117}$ The author conducted a comparative study with other systems such as DDC and LCC, and tested the new system with a survey in the central McGill University on the disciplines of Islam and of LIS.

Mills also examines the relationship between classification and IR, specifically faceted classification and its use within IR systems. ${ }^{118}$ As a long-time expert in library classification, Mills's insight into this relationship and his review of the fundamental process of faceted classification, especially the general role of logical division, is invaluable. Using the new Bliss Classification System (BC2), he discusses the six fundamental steps taken in classifying with a faceted system, including the division of a subject into facets, facets into arrays, and citation order. Finding a journal article that provides detailed description on the process of classifying is a rarity.

Beghtol maintains that classifications for IR are called "professional" classifications because they are devised by people who have a professional interest in classification. ${ }^{119}$ She states that classifications for knowledge discovery are called naive classifications because they are devised by people who have no particular interest in studying classification as an end to itself. Beghtol stresses that classification for knowledge discovery has been less explored than classification for IR. She explores these two categories and discusses methods for construction of naive classification systems. In 
another article, Beghtol brings attention to the subject classification system of James Duff Brown and the fact that he has not yet received the recognition for his contribution to the study of classification. ${ }^{120}$ She suggests that "any research field is enhanced by inquiring into its intellectual history and background, both by increasing our comprehension of the past and by refining our understanding of the activities of the present." 121

Other areas of librarianship have also explored the use of classification for resource discovery. Goldberg examines historical and political aspects of the development of law classification seen in LCC's schedule K and how it relates to the development of a universal law classification. ${ }^{122}$ Others examine adapting DDC for use in a feminist/women's-issues context in an effort to demonstrate that adaptation to a particular culture or context is possible. ${ }^{123}$ Campbell describes the classification of economic data by comparing the North American Industry Classification System (NAICS) and LCC. ${ }^{124}$ In particular, he asks how a statistical classification scheme differs from a bibliographic classification scheme in its representation of different countries, and what mechanism each uses to facilitate comparison and cross-analysis of common topics in different countries.

\section{Information Organization Education}

Education in the organization of information objects, both presently and in future information environments, is a sensitive subject that is always on the frontlines. It is often the center of passionate debates, particularly now with the amount of change catalogers can expect in their tools (that is, RDA), resources, and users.

Hill, an established advocate for information organization education, gives a historical account of cataloging education in library schools in part I of a two-part article, paying particular attention to instructional delivery, the use of adjuncts to teach the courses, the substance of courses, and the decrease in library schools' commitment to require cataloging courses. ${ }^{125}$ Part II addresses the issue of cataloging training in the classroom versus training in the work place. Hill states there is a "yawning chasm between libraryspecific practice and history and principles. The chasm is called 'Understanding and Applying Cataloging Rules and Standards,' and is one that all catalogers must cross." ${ }^{\text {"126 }}$ She discusses advantages and disadvantages to workplace training and examines a few helpful external resources. Perhaps the most significant words Hill imparts to her readers are found in her admonishment of library schools for neglecting to provide appropriate training of up-and-coming catalogers. She writes, "One of the consequences of the evolution of the collective LIS curriculum to include proportionately less about cataloging and bibliographic control is that fewer librarians have a real understanding and appreciation of cataloging, of all that it entails, of all that it does, and why it matters." ${ }^{\text {"27 }}$ Hill ends her discussion on cataloging education rhetorically by questioning why it is needed at all. She concludes that "education for cataloging is no more an obsolete concept than is education for librarianship." ${ }^{28}$ It has transformed, of course, but it has not disappeared.

Hsieh-Yee also addresses cataloging education by surveying 52 ALA-accredited LIS graduate program directors about their cataloging and metadata curricula. ${ }^{129}$ She found an increased reliance on introductory courses to introduce essential cataloging and metadata concepts, and fewer required cataloging courses. While she found a high percentage of cataloging courses offered, there was an overall lack of consensus on exactly what the courses should cover. Cataloging educators are split on the issue of whether cataloging is metadata or if they are two different areas. She states that "most of them considered many of the topics equally relevant to students who aspire to be catalogers and those aspiring to be metadata specialists." 130 The survey results allowed for recommendations to be made in response to Action Item 5.1 of LC's Bibliographic Control of Web Resources: A Library of Congress Action Plan. ${ }^{131}$

The issue of continuing education for catalogers is just as contentious because it reveals both the failure of many library schools in teaching the basics and the failure of catalogers to keep current with their professional requirements. Moreover, failure to support continuing education often reveals the failure of library administrators to recognize the value of catalogers. For example, one can search the Autocat electronic discussion list archives and read quite a few passionate threads on the topic. ${ }^{132} C C Q$ has published interviews with experienced catalogers that provide a sense of the work involved, the issues addressed, and opinions of the impending changes on the horizon. ${ }^{133}$

\section{Local and International Authority Control, and Quality Control}

The International Conference on Authority Control: Definition and International Experiences was held in Florence, Italy on February 10-12, 2003. ${ }^{134}$ Participants gave presentations on standards and exchange formats, control of names and subjects, theoretical aspects concerning authority control and authority-control education in LIS schools, conceptual models, international systems of authority control, impediments to appropriate authority control in online catalogs, UNIMARC format for authority records, and authority work for names, works, and subjects. Igino Poggiali, then National President of the Italian Library Association, gave the opening remarks in which he commented on the outsourcing of authority work: 
Whether the work is done inside the library or the task is outsourced, the real problem is the availability of a really professional staff able to face the complexity of these new challenges. The series of problems in which treatment of authority control is set requires a high cultural level of preparation of operators, and a great openness to cultures and ways of thinking that are different and remote. How many of us are really prepared at this level? ${ }^{135}$

Many of the papers describe projects from different countries. For example, Fabian discusses the thesaurus of names, printers, publishers, and persons used by the Consortium of European Research Libraries (CERL). ${ }^{136}$ $\mathrm{Hu}$, Tam, and Lo give an overview of Asian authority control, and Messmer describes the German name-authority file in the Bavarian Union Catalogue. ${ }^{137}$

Boese examines the cost of authority control and explains how the investment in a strong authority database can lessen future catalog maintenance costs. ${ }^{138}$ Delsey discusses the international sharing of authority data and the proposal of the International Standard Authority Data Number (ISADN) that would establish links between multiple sources. ${ }^{139}$ He sees a potential to support large-scale uploading of authority files to national and multinational databases through the use of automated routines, which reduce the level of human intervention needed. Graham and Ross explore authority control in the Civil Rights in Mississippi Digital Archive and discuss how the project has enabled Name Authority Cooperative Program (NACO) and Series Authority Cooperative Program (SACO) member libraries to add local name and subject headings, thereby allowing LC to fill in gaps in the corresponding subjects areas. ${ }^{140}$

There is also the curiously ignored issue of nonroman scripts in bibliographic and authority records. Plettner gives a brief history of Arabic name authority control that centers on whether or not to use both dual-script records, Latin and Arabic, or just one script. ${ }^{141}$ Current technology still requires a dominant language. The implementation of nonroman script bibliographic records in the United States has eased the situation for bibliographic records, but not as much for authority records. RLIN and OCLC are leaders in implementing Arabic language authority records, but Arabic language catalogers must adhere to the input methods required by the two bibliographic institutions. Plettner points out that "since less than half the world uses Latin scripts exclusively, the inclusion of nonroman scripts in any future plans is essential. The challenge now is to implement this encoding capability in a uniformly standardized way and to encourage its adoption by all libraries." ${ }^{242}$ She specifically sites the success of UNICODE as an international standard and also examines MARC21 and how groups such as ALA's
Machine-Readable Bibliographic Information Committee (MARBI) are dealing with this situation and suggests that a supranational group would better serve the consensus on authority control at an international level. Plettner proposes that a model for an international name authority clearinghouse be implemented to save the time of both the cataloger and the user.

International efforts in bibliographic control can also be seen in the proceedings of the eighth conference of the International Society for Knowledge Organization (ISKO) held in London in July $2004 .{ }^{143}$ University College London hosted the conference, entitled "Knowledge Organization and the Global Information Society." Fifty-four papers were presented on knowledge organization topics ranging from theoretical foundations, linguistic and cultural approaches, social and sociological concepts, to user perceptions, universal and special systems of organization (e.g., UDC, DDC, analytico-synthetic classification systems), nonprint materials (e.g., electronic documents, images, medical), and applications of artificial intelligence and knowledge representations.

Finally, in keeping with the FRBRization issue, Patton reports on the IFLA Working Group on FRANAR. ${ }^{144}$ Quite simply, FRBR does not address functional requirements of authority records. The aim of the working group was to define the requirements, the use, and the user, as well as a possible ISADN. This initial conceptual model depicts five "'primitive' entities" (being, thing, concept, event, and situation) mapped to FRBR entities as well as entities that "reflect the logical groupings of data that make up an authority file." 145 Other relationships such as linking relationships and relationships between and among entities are also explored. User tasks are described in terms of resource discovery (search, identify, control, and relate) and data management (process, sort, display, and integrate.) ${ }^{146}$

Beyond the issue authority work in general is the pursuit of overall quality of data in bibliographic and authority databases. Paiste's review of the literature of quality control notes the evolving nature of quality, particularly throughout the 1980s and 1990s. ${ }^{147}$ She offers ways for catalogers to maintain quality by using management expert W. Edwards Deming's fourteen points to transform an organization (e.g., assessing user needs and expectations, strategic planning). Paiste strongly urges catalogers to keep in focus the purpose of their activities. She likens the modern quality environment to a medieval guild: "Training occurs first, there is quality at the source, and workers do not pass on known defects. Workers have a view of the whole product and take pride in their workmanship." 148

Beall and Kafadar point out that the efficiency of copy cataloging can be accompanied by inefficiency due to typographical errors in those same records. ${ }^{149}$ The authors noted 100 errors found within 500 records in the OCLC 
WorldCat database and traced the records containing the errors back to five libraries to see if corrections had been made. They measured how successful copy catalogers were at finding and correcting typographical errors. The findings indicate that, of the 500 records examined, only 35.8 percent were corrected and 64.2 percent were uncorrected. While this is a small study, the results are still shocking enough to warrant more in-depth research of why these errors are uncorrected and how libraries can ensure better quality control of their databases. Beall and Kafadar offer several reasonable suggestions for such future studies. Kulczak and Reineka report on the measurement of the quality of headings in Government Printing Office records supplied by Marcive and found that, while the overall quality was good, a significant percentage of headings in the authority reports required additional attention. ${ }^{150}$

Shin reports on an assessment of 2,000 Koreanlanguage bibliographic records in WorldCat and considers specific errors, error frequency, areas where errors occur frequently, and errors that could inhibit record retrieval. ${ }^{151}$ Shin found patterns in the errors involving ISBD punctuation, missing variable and fixed fields, and that these patterns are similar to other studies. Romanization errors were also of great concern because of the resulting retrieval difficulties. Shin offers eight recommendations to enhance the quality of Korean records.

Following on the heels of his 2002 occasional paper on the misinformation in shared library catalogs, Bade published two works addressing similar issues. The first is a self-published work that examines in detail 175 records in OCLC's WorldCat database to study "failure of competence or attention in the cataloger." 152 A 2004 book is a longer treatise on more theoretical issues of misinformation. ${ }^{153}$ Here Bade divides the content into several categories - the theoretical aspects of error, theory, and practice of bibliographic failure, taxonomies of error, and misinformation and the disorders of significance. He provides a comprehensive review of comparable literature and a strong argument for self-detection, self-correction, and self-assessment within the information organization environment in any library, even though he concentrates solely on academic libraries. The taxonomy of errors in part III alone is a valuable contribution to LIS. Bade writes that "origins of errors in bibliographic databases range from purely mechanical and predictable causes, to nonpredictable errors arising from software and hardware design and operation beyond the control of the cataloger" and that his classification is intended to provoke interest and discussion. ${ }^{154}$ The taxonomy is comprehensive and impossible to completely relate here, but the broader classes include such topics as policies as error engines, mechanical origins, human-computer interaction, psychological factors, methodology, linguistics origins, and subjective incompetence. The bibliography is extensive and would enhance any LIS curriculum, particularly information organization and technical service. Bade concludes the book by asking his readers to imagine "putting 'science' back into Library Science" and reminds the reader that "constant attention to error, to identifying, correcting, and learning" from science is the life of science. ${ }^{155}$ To provoke discussion or action may be the author's ultimate goal with this work, but the undertone is to use plain old common sense when it comes to quality descriptive and subject cataloging.

Lastly, MacEwan and Young examined the quality of bibliographic records at the British Library with the aim of developing a robust, accurate, and consistent methodology that can act as a reliable management information tool for reporting on the effectiveness (quality and accuracy) of the Library's cataloging service. ${ }^{156}$ FRBR concepts and its usertask focus were used as a measurement for quality.

\section{Subject Retrieval and Access, Multilingual Issues}

In 2001, an IFLA satellite meeting on subject retrieval was held in Dublin, Ohio. McIlwaine remarks in the introduction of the published proceedings that "we are not indulging in anything new. We are following in very well-trodden footsteps, and the organization of information has been practiced by governments for more than two and a half millennia. The principal differences that face us today are the speed with which information is amassed and the quantities of it, together with the constant economic pressures."157

Papers presented at several different sessions focused on subject retrieval and access several different sessions: retrieval in multilingual environments, retrieval across multiple vocabularies, cross-sectoral retrieval, domain-specific retrieval, retrieval tool development, and transformation of traditional tools for the Web environment. Riesthuis discusses issues surrounding a multilingual thesauri that would allow for access to information using another (natural) language than the language of the information itself, as well as the problems associated with such an effort (e.g., stretching a language to make it fit a foreign structural concept). ${ }^{158} \mathrm{He}$ stresses that cataloging and subject-indexing rules have not kept up with these developments and that subject-access tools need to be more user intuitive. Kuhr describes similar efforts of combining subject headings from multiple disciplines and their corresponding controlled vocabularies using algorithms. ${ }^{159}$ Olson reports on the mapping and integration of LCSH and the National Library of Medicine's Medical Subject Headings (MeSH) ${ }^{160}$ Bean and Green suggest the use of integrated structures, called frame representations, in order to standardize syntagmatic relationship types on the conceptual level and to provide higher precision in electronic retrieval of text. ${ }^{161}$ 
A major trend in subject-access work is the combining, or mapping, of traditional subject-access tools and the increasing multilingual issues worldwide. The Multilingual Access to Subjects (MACS) project is one example of this important work. ${ }^{162}$ Creider surveyed academic libraries about the use of Spanish-language subject headings, an area in which very little research has been done, and found that 48 percent of the libraries "routinely removed Spanish language subject headings already present on cataloging copy, while 58 percent left them in their records and that only 5 percent of the respondents actually added Spanish subject headings." ${ }^{63}$ Another important aspect of subject access often ignored is the problem of multiple interpretations of meaning by catalogers and indexers. Šauperl has developed a model of subject cataloging based on twelve catalogers that she feels will contributes empirical evidence to the theory and practice of indexing. ${ }^{164}$ One conclusion reached in the development of the model was that "catalogers are in fact aware of the multiple meanings that subject headings may have for different people in different situations, and that catalogers actually try to limit those multiple meanings." 165

Lastly, the Faceted Application of Subject Terminology (FAST), a simplified approach to assigning LCSHs, has been developed by adapting a "faceted schema with a simplified syntax," while retaining the richness of LCSH. ${ }^{166}$ It is a postcoordinated vocabulary system specifically intended for the Web environment and has been designed for easy use with embedded metadata and automated authority control. ${ }^{167}$

\section{Summary}

The rapid changes taking place with cataloging rules, standards, and the tools and resources used by catalogers have been the focus of much of the literature during 2003 and 2004. In particular, FRBR has hit the field much like a tsunami-striking with little mercy and rearranging the landscape, rendering traditional and accepted cataloging concepts as obsolete or illogical in the twenty-first-century information environment. Whether or not it is fully integrated or accepted by all those concerned remains unanswered.

Interoperability between multiple systems has been addressed, as has multilingual subject access, especially in works presented at international conferences. This corresponds with the issues of nonroman character usage in major bibliographic databases. Issues surrounding authority control, classification, and cataloging principles in general, can be found in several compilations of works.

The urge to move away from MARC and into a pure XML work is still the focus of much research and debate. LC has provided the opportunity for those libraries interested to convert their MARC records to XML; OCLC's WorldCat database now employs an XML metadata schema; and books are appearing that show librarians ways to incorporate XML into their daily work environments. On the opposite side of the debate are researchers who have striven to demonstrate that MARC has been misunderstood, misused, and quite often underutilized. The undertones of some authors addressing this debate suggest that moving to a different markup language would potentially allow for previously resolved problems to reoccur cloaked as new ones. Along the same line, educators of catalogers are urged to take into account all the issues discussed above, in addition to teaching the fundamental bibliographic rules and standards.

The two years of literature reviewed here reflect the challenge catalogers face in preparation for the significant changes in practice that will take place within a few short years (e.g., Resource Description and Access is due to be published in 2008). Globalization and the variability of language and practice that accompanies it, as well as the continued digitization of formats, will all be affected by the ideas presented in the Functional Requirements for Bibliographic Records.

\section{References}

1. "Statement of International Cataloguing Principles," Draft approved by the IFLA Meeting of Experts on an International Cataloguing Code, 1st, Frankfurt, Germany, 2003. www.ddb .de/standardisierung/pdf/statement_draft.pdf\#search=\%22 Statement\%200f\%20International\%20Cataloguing\%20 Principles\%22 (accessed Jul. 13, 2005); Barbara Tillett et al., eds., IFLA Cataloguing Principles: Steps Toward an International Cataloguing Code: Report from the 1st IFLA Meeting of Experts on an International Cataloguing Code, IFLA Series on Bibliographic Control (München, Germany: K. G. Saur, 2004), 26; International Federation of Library Associations, Statement of Principles Adopted at the International Conference on Cataloguing Principles, Paris, Oct., 1961. Annotated edition with commentary and examples by Eva Verona (London: IFLA Committee on Cataloguing, 1971).

2. IFLA Study Group on the Functional Requirements for Bibliographic Records, Functional Requirements for Bibliographic Records: Final Report (München, Germany: K. G. Saur, 1998), www.ifla.org/VII/s13/frbr/frbr.pdf (accessed July 13, 2005); Patton, "FRANAR: A Conceptual Model for Authority Data," Cataloging \& Classification Quarterly 38, no. 3/4 (2004): 91-104.

3. IFLA Study Group on the Functional Requirements for Bibliographic Records, Functional Requirements for Bibliographic Records: Final Report.

4. Elaine Svenonius, The Intellectual Foundation of Information Organization (Cambridge, Mass.: MIT Pr., 2000).

5. "Statement of International Cataloguing Principles: Draft Approved by the IFLA Meeting of Experts on an International Cataloging Code, 1st, Frankfurt, Germany, 2003," www.ddb .de/standardisierung/pdf/statement_draft.pdf (accessed Nov. 9, 2006).

6. Tom Storey, "OCLC Explores the Implications of What Could Be the Biggest Change to Library Catalogs in More than a 
Century,” OCLC Newsletter no. 262 (Oct./Nov./Dec. 2003), www.oclc.org/news/publications/newsletters/oclc/2003/262/ frbr.htm (accessed July 19, 2006).

7. OCLC, "FRBR Work-Set Algorithm," www.oclc.org/research/ software/frbr (accessed June 25, 2006).

8. Barbara Tillett, "FRBR (Functional Requirements for Bibliographic Records)," Technicalities 23, no. 5 (Sept./Oct. 2003): 1 .

9. IFLA Study Group on the Functional Requirements for Bibliographic Records, Functional Requirements for Bibliographic Records: Final Report; Shoichi Taniguichi, "Expression-Level Bibliographic Entity Records: A Trial on Creation from Preexisting MARC Records," Cataloging \& Classification Quarterly 38, no. 2 (2004): 33-59.

10. Shoichi Taniguichi, "Conceptual Modeling of Component Parts of Bibliographic Resources in Cataloging," Journal of Documentation 59, no. 6 (2003): 692-708.

11. Shoichi Taniguichi, "Design of Cataloging Rules Using Conceptual Modeling of Cataloging Process," Journal of the American Society for Information Science and Technology 55, no. 6 (2004): 498-512.

12. Kristin Antelman, "Identifying the Serial Work as a Bibliographic Entity," Library Resources \& Technical Services 48, no. 4 (2004): 238-55.

13. Ibid., 239.

14. Ibid., 250 .

15. Rick Bennett, Brian F. Lavoie, and Ed O’Neill, "The Concept of a Work in WorldCat: an Application of FRBR," Library Collections, Acquisitions, \& Technical Services 27, no. 1 (2003): 45-59; Karen Coyle, "Future Considerations: The Functional Library Systems Record," Library Hi-Tech 22, no. 2 (2004): 166-74.

16. Mauro Guerrini, "GMD: Its Function and Its History," Cataloging \& Classification Quarterly 38, no. 2 (2004): 61-74.

17. Chris Oliver, "FRBR is Everywhere, But What Happened to the Format Variation Issue?" Serials Librarian 45, no. 4 (2004): 27-36.

18. Pat Riva, "Mapping MARC 21 Linking Entry Fields to FRBR and Tillett's Taxonomy of Bibliographic Relationships," Library Resources \& Technical Services 48, no. 2 (2004): $130-43$.

19. Ibid., 139.

20. Amy Chapman and Alan Danskin, "A New Direction for Bibliographic Records? The Development of Functional Records for Bibliographic Records," Catalogue and Index no. 149 (Autumn 2003): 11.

21. Olivia M. A. Madison, "Association for Library Collections and Technical Services Annual Report 2002/2003," Library Resources \& Technical Services 48, no. 1 (Jan. 2004): 4-11.

22. Knut Hegna and Eeva Murtomaa, "Data Mining MARC to Find: FRBR?” International Cataloguing and Bibliographic Control 32, no. 3 (July/Sept. 2003): 52-55.

23. Marie-Louise Ayres et al., "Report on the Successful AustLit: Australian Literature Gateway Implementation of the FRBR and INDECS Event Models, and Implications for Other FRBR Implementations," International Cataloguing and Bibliographic Control 32, no. 1 (Jan./March 2003): 8-13.
24. Ibid., 9 .

25. Ya-ning Chen and Shu-juin Chen, "A Metadata Practice of the IFLA FRBR Model: A Case Study for the National Palace Museum in Taipei," Journal of Documentation 60, no. 2 (2003): 128-43.

26. Ibid., 137.

27. Lynne Howarth, "Enabling Metadata: Creating Core Records for Resource Discovery," World Library and Information Congress: 70th IFLA General Conference and Council, Aug. 22-27, 2004, Buenos Aires, Argentina, www.ifla.org/IV/ifla70/ papers/008e-Howarth.pdf (accessed July 13, 2005).

28. Ibid., 7.

29. Stephen Abrams, "Why Should I Care About Standards?" Information Outlook 7, no. 3 (2003): 21.

30. Ibid.

31. Sally H. McCallum, "An Introduction to the Metadata Object Description Schema (MODS),” Library Hi Tech 22, no. 1 (2004): 82-88.

32. Leif Andresen, "After MARC_-What Then?" Library Hi Tec, 22, no. 1 (2004): 40-51.

33. Ibid., 46.

34. Ibid., 43.

35. Roy Tennant, "A Bibliographic Metadata Infrastructure for the Twenty-first Century," Library Hi Tech 22, no. 2 (2004): 175-81.

36. Roy Tennant, "Not Your Mother's Union Catalog," Library Journal 128, no. 7 (2003): 28.

37. Judith Wusteman, “About XML: Patently Ridiculous," Library Hi-Tech 22, no. 1 (2004): 231-37.

38. Joaquim Ramos de Carvalho et al., "Meta-information About MARC: An XML Framework for Validation, Explanation, and Help Systems," Library Hi-Tech 22, no. 2 (2004): 131-37.

39. Ibid., 136.

40. Library of Congress, Network Development and MARC Standards Office, "MARCXML: MARC 21 XML Schema" (July 26, 2006), www.loc.gov/standards/marcxml (accessed Sept. 30, 2006).

41. Library of Congress, Network Development and MARC Standards Office, "MARCXML Instance," (2005). www.loc .gov/standards/marcxml/Sandburg/sandburg.xml (accessed July 21, 2005).

42. Library of Congress, Network Development and MARC Standards Office, "MARCXML: MARC 21 XML Schema."

43. Corey Keith, "Using XSLT to Manipulate MARC Metadata," Library Hi-Tech 22, no. 2 (2004): 122-30.

44. Dick R. Miller and Kevin S. Clarke, Putting XML to Work in the Library: Tools for Improving Access and Management (Chicago: ALA, 2004).

45. Priscilla Caplan, Metadata Fundamentals for All Librarians (Chicago: ALA, 2003); David Haynes, Metadata for Information Management and Retrieval (London: Facet Pubs., 2004).

46. Bradford Eden, "Metadata and Librarianship: Will MARC survive?" Library Hi-Tech 22, no. 1 (2004): 6-7.

47. Michael Gorman, "Cataloguing in an Electronic Age," Cataloging \& Classification Quarterly 36, no. 3/4 (2003): 5-17.

48. Ibid., 8-9. 
49. Andresen, "After MARC—What Then?"

50. Roy Tennant, "Metadata Leadership," Library Journal 129, no. 13 (2004): 27.

51. Martha Yee, "New Perspectives on the Shared Cataloging Environment and a MARC 21 Shopping List," Library Resources \& Technical Services 48, no. 3 (2004): 165-78.

52. Ibid., 175.

53. Peter Carini and Kelcy Shepard, "The MARC Standard and Encoded Archival Description," Library Hi-Tech 22, no. 1 (2004): 18-27.

54. Susan E. Davis, "Descriptive Standards and the Archival Profession," Cataloging \& Classification Quarterly 35, no. 3/4 (2003): 291-308.

55. Katherine M. Wisser and Jennifer O’Brien Roper, “Maximizing Metadata: Exploring the EAD-MARC Relationship," Library Resources \& Technical Services 47, no. 2 (2003): 71-76.

56. Jane W. Jacobs, Ed Summers, and Elizabeth Ankersen, "Cyril: Expanding the horizons of MARC21," Library Hi Tech 22, no. 1 (2004): 8-17.

57. Janet K. Smith et al., "MARC to ENC MARC: Bringing the Collection Forward," Library Hi-Tech 22, no. 1 (2004): 28-39.

58. Brian E. Surratt and Dustin Hill, "ETD2MARC: A Semiautomated Workflow for Cataloging Electronic Theses and Dissertations," Library Collections, Acquisitions, \& Technical Services 28, no. 2 (Summer 2004): 205-23.

59. Erik Jul, "MARC and Mark-Up," Cataloging \& Classification Quarterly 36, no. 3/4 (2003): 141-53.

60. Jane L. Hunter, "A Survey of Metadata Research for Organizing the Web," Library Trends 52, no. 2 (Fall 2003): 318-44.

61. Anglo-American Cataloguing Rules, 2nd ed., rev., with 2004 updates (Ottawa: Canadian Library Assoc.; London: Library Assoc. Publishing; Chicago: ALA, 2002); Joint Steering Committee for the Revision of the Anglo-American Cataloguing Rules, "Historic Documents," (June 19, 2006). www .collectionscanada.ca/jsc/docs.html\#amend (accessed Sept. 30, 2006).

62. Cataloging Policy and Support Office, "Library of Congress Implementation of the 2003 Update to the 2002 AACR2" (July 22, 2003), www.lcweb.loc.gov/catdir/cpso/2003upd.html (accessed Sept. 30, 2006).

63. Linda Gonzalez, "2004 Update of AACR2 released by ALA in August," Action for Libraries-October 2004, www.bcr .org/publications/afl/2004/october/aacr2update.html/accessed July 14, 2005).

64. Ibid.

65. Joint Steering Committee for the Revision of the AngloAmerican Cataloguing Rules "Historic Documents."

66. Deborah Fritz, Cataloging with AACR2 and MARC: For Books, Electronic Resources, Sound Recordings, Videorecordings, and Serials, 2nd ed. (Chicago: ALA, 2004).

67. Ibid., ix.

68. Deborah Fritz and Richard Fritz, MARC21 for Everyone: A Practical Guide (Chicago: ALA, 2003).

69. Robert L. Maxwell, Maxwell's Handbookfor AACR: Explaining and Illustrating the Anglo-American Cataloguing Rules, through the 2003 update (Chicago: ALA, 2004).
70. Ibid., ix

71. Arlene Taylor, Wynar's Introduction to Cataloging and Classification, 9th rev. ed. (Westport, Conn.: Libraries Unlimited, 2004).

72. J. H. Bowman, Essential Cataloguing (London: Facet Pubs., 2003), 2.

73. Ibid.

74. Jane M. Read, Cataloguing Without Tears: Managing Knowledge in the Information Society (Oxford, England: Chandos Pubs., 2003).

75. Ibid., xiii.

76. Anglo-American Cataloguing Committee for Cartographic Materials, Cartographic Materials: A Manual of Interpretation for AACR2, 2002 Rev. (Chicago: ALA, 2003).

77. Ibid., 2

78. Anglo-American Cataloguing Committee for Cartographic Materials, Cartographic Materials: A Manual of Interpretation for AACR2, 2002 rev., 2004 update, (Chicago: ALA, 2004).

79. Paige G. Andrew, Cataloging Sheet Maps: The Basics (New York: Haworth, 2003).

80. Ibid., xiv.

81. Shelia Intner et al., eds., Electronic Cataloging: AACR and Metadata for Serials and Monographs (New York: Haworth, 2003), 4.

82. Steven Shadle, "A Square Peg in a Round Hole: Applying AACR2 to Electronic Journals," in E-Serials: Publishers, Libraries, Users, and Standards, 2nd ed., ed. Wayne Jones (New York: Haworth, 2003), 119-39.

83. Jim Cole, "Chapter 9: Electronic Serials: Searching for a Chief Source of Information," in E-Serials: Publishers, Libraries, Users, and Standards, 2nd ed., ed. Wayne Jones (New York: Haworth, 2003), 141-53.

84. Gregory Wool, "Chapter 10: A Meditation on Metadata," in E-Serials: Publishers, Libraries, Users, and Standards, 2nd ed., ed. Wayne Jones (New York: Haworth, 2003), 155-65.

85. Anita Coleman, Guide to Selecting and Cataloging Quality $W W W$ Resources for the Small Library (Fairfield, Calif.: Learning Resources Association of the Calif. Community Colleges, 2004), 11

86. Ibid., 13 .

87. Susan L. Scheiberg and Shelley Neville, eds., "Transforming Serials: The Revolution Continues," Proceedings of the North American Serials Interest Group, 17th Annual Conference, June 20-23, 2002 (New York: Haworth, 2003); eds. Patricia Sheldahl French and Richard Worthing, "Serials in the Park," Proceedings of the North American Serials Interest Group, 18th Annual Conference, June 26-29, 2003 (New York: Haworth, 2004).

88. Ibid.

89. Jay Weitz, Cataloger's Judgment: Music Cataloging Questions and Answers from the Music OCLC Users Group Newsletter, ed. Matthew Sheehy (Westport, Conn.: Libraries Unlimited, 2004).

90. Ibid., xix-xx.

91. Ibid., xviii-xix.

92. Holly Ann Gardinier, "Access Points Perceived as Useful in Searching for Music Scores and Recordings" (Ph.D. diss., University of California, Los Angeles, 2004). 
93. Melvil Dewey, Dewey Decimal Classification and Relative Index, 22nd ed., eds. Joan S. Mitchell et al., 4 vols. (Dublin, Ohio: OCLC, 2003), xi.

94. Melvil Dewey, Abridged Dewey Decimal Classification and Relative Index, 14th ed., eds. Joan S. Mitchell et al. (Dublin, Ohio: OCLC, 2004).

95. Dewey, Dewey Decimal Classification and Relative Index, 22nd ed., xix.

96. "New Features in Edition 22," Dewey Decimal Classification and Relative Index, 22nd ed., eds. Joan S. Mitchell et al., vol. 1 (Dublin, Ohio: OCLC, 2003).

97. Joan Mitchell and Lois Mai Chain, Dewey Decimal Classification: Principles and Application, 3rd ed. (Dublin, Ohio: OCLC, 2003).

98. Eunice Kua, "Non-Western Languages and Literatures in the Dewey Decimal Classification Scheme," Libri 54, no. 4 (2004): 256-65.

99. Andrea L. Stamm, "Foreword by the Decimal Classification Editorial Policy Committee," Dewey Decimal Classification and Relative Index, 22nd ed., xi-xiii, (Dublin, Ohio: OCLC, 2003).

100. Cataloging Distribution Service, Library of Congress, "LC Classification Schedules and Manuals from CDS" (Aug. 11, 2006), www.loc.gov/cds/classif.html (accessed Sept. 30, 2006).

101. Universal Decimal Classification Consortium, Extensions and Corrections to the UDC (Jan. 29, 2006). www.udcc.org/ec.htm (accessed Sept. 30, 2006).

102. Aida Slavic, "UDC Implementation: From Library Shelves to a Structured Indexing System," Extensions and Corrections to the UDC, no. 25 (2003), www.udcc.org/ec25_2003.htm (accessed Jul. 17, 2005).

103. Nancy Williamson and Clare Beghtol, eds., Knowledge Organization and Classification in International Information Retrieval (New York: Haworth, 2003).

104. Minnie Earl Sears, Sears List of Subject Headings, 18th ed., Joseph Miller, ed. (New York: Wilson, 2004); Library of Congress, Cataloging Policy and Support Office, Library of Congress Subject Headings, 26th ed., (Washington, D.C.: Library of Congress, Cataloging Distribution Service, 2003); Library of Congress, Cataloging Policy and Support Office, Library of Congress Subject Headings, 27th ed., (Washington, D.C.: Library of Congress, Cataloging Distribution Service, 2004); Library of Congress, Cataloging Policy and Support Office, Subject Cataloging Manual: Subject Headings, 5th ed., 2004 cumulation (Washington, D.C.: Library of Congress, Cataloging Distribution Service, 2004).

105. Vanda Broughton, Essential Classification (New York: NealSchuman, 2004), 1.

106. Ibid., 1.

107. Martin D. Joachim, ed., Historical Aspects of Cataloging and Classification (New York: Haworth, 2003).

108. Elisabeth de Rijk Spanhoff, "Principle Issues: Catalog Paradigms, Old and New," in Historical Aspects of Cataloging and Classification, ed. Martin D. Joachim (New York: Haworth, 2003), 37-59.

109. Cataloging \& Classification Quarterly, "Cataloging \&
Classification Quarterly News and Announcements" (Mar. 29 , 2005). www.catalogingandclassificationquarterly.com/ ccqnewstuff.html (accessed July 17, 2005).

110. Carol June Bradley, "Classifying and Cataloguing Music in American Libraries: A Historical Overview," in Historical Aspects of Cataloging and Classification, Martin D. Joachim, ed. (New York: Haworth, 2003), 467-81; Lawrence Simpson Guthrie II, "Monastic Cataloging and Classification and the Beginning of 'Class B' at the Library of Congress," in Historical Aspects of Cataloging and Classification, ed. Martin D. Joachim (New York: Haworth, 2003), 447-65.

111. Richard Smiraglia, "The History of 'The Work' in the Modern Catalog," in Historical Aspects of Cataloging and Classification, ed. Martin D. Joachim (New York: Haworth, 2003), 553-67.

112. Jens-Erik Mai, "The Future of General Classification," Cataloging \& Classification Quarterly 37, no. 1/2 (2003): 3-12.

113. Ibid., 11.

114. Lisa Zhao, "Save Space for 'Newcomers'-Analyzing Problems in Book Number Assignment Under the LCC System," Cataloging \& Classification Quarterly 38, no. 1 (2004): 105-19.

115. Eibe Frank and Gordon W. Paynter, "Predicting Library of Congress Classifications From Library of Congress Subject Headings," Journal of the American Society for Information Science and Technology 55, no. 3 (2004): 214-27.

116. Gholamreza Fadaie Araghi, "A Dynamic Look Toward Classification and Retrieval," Cataloging \& Classification Quarterly 38, no. 1 (2004): 43-53.

117. Gholamreza Fadaie Araghi, "A New Scheme for Library Classification," Cataloging \& Classification Quarterly 38, no. 2 (2004): 75-99.

118. Jack Mills, "Faceted Classification and Logical Division in Information Retrieval," Library Trends 52, no. 3 (Winter 2004): 541-70.

119. Clare Beghtol, "Classification for Information Retrieval and Classification for Knowledge Discovery: Relationships between 'Professional' and 'Naïve' Classifications," Knowledge Organizations 30, no. 2 (2003): 64-73.

120. Clare Beghtol, "Exploring New Approaches to the Organization of Knowledge: The Subject Classification of James Duff Brown," Library Trends 52, no. 4 (Spring 2004): 702-18.

121. Ibid., 702.

122. Jolande E. Goldberg, "Development of a Universal Law Classification: A Retrospective on Library of Congress Class K," Cataloging \& Classification Quarterly 35, no. 3/4 (2003): 355-436.

123. Angela Kublik et al., "Adapting Dominant Classifications to Particular Contexts," Cataloging \& Classification Quarterly 37, no. 1/2 (2003): 13-31.

124. D. Grant Campbell, "Global Abstractions: The Classification of International Economic Data for Bibliographic and Statistical Purposes," Cataloging \& Classification Quarterly 37, no. 1/2 (2003): 221-34.

125. Janet Swan Hill, "Education and Training of Catalogers: Obsolete? Disappeared? Transformed?-Part I," Technicalities 24, no. 1 (2004): 1. 
126. Janet Swan Hill, "Education and Training of Catalogers: Obsolete? Disappeared? Transformed?-Part II," Technicalities 24, no. 2 (2004): 1.

127. Ibid.

128. Ibid.

129. Ingrid Hsieh-Yee, "Cataloging and Metadata Education in North American LIS Programs," Library Resources \& Technical Services 48, no. 1 (2004): 59-68.

130. Ibid., 65.

131. Library of Congress, Bibliographic Control of Web Resources: A Library of Congress Action Plan (last updated Feb. 23, 2005), www.loc.gov/catdir/bibcontrol/actionplan.pdf (accessed Aug. 3, 2005).

132. University of Buffalo, "AUTOCAT listserv archive." http://list serv.acsu.buffalo.edu/archives/autocat.html (accessed Aug. 4, 2005).

133. Sandra K. Roe, “An Interview with Jean Weihs, Nancy B. Olson, and Vern Urbanski (October 2002)," Cataloging \& Classification Quarterly 36, no. 1 (2003): 3-23; Mary S. Woodley, "An Interview with Sara Shatford Layne," Cataloging \& Classification Quarterly 36, no. 2 (2003): 3-16.

134. Arlene Taylor and Barbara Tillett, "Preface" Cataloging \& Classification Quarterly, 32, no. 3/4 (2004): xxiii-xxvii.

135. Igino Poggiali, "Welcome to Participants," Cataloging \& Classification Quarterly 32, no. 3/4 (2004): 1-3.

136. Claudia Fabian, "The CERL Thesaurus File," Cataloging \& Classification Quarterly 39, no. 1/2 (2004): 413-20.

137. Lily $\mathrm{Hu}$ et al, "Chinese Name Authority Control in Asia: An Overview," Cataloging \& Classification Quarterly 39 no. 1/2 (2004): 465-88; Gabriele Messmer, "The German Authority File (PND) in the Bavarian Union Catalog: Principles, Experiences, and Costs," Cataloging \& Classification Quarterly 39, no. 1/2 (2004): 421-27.

138. K. C. Boese, "What's in a Name: Associated Costs of Authority Work for Artist's Names," The Bottom Line: Managing Library Finances 16, no. 3 (2003): 106-10.

139. Tom Delsey, "Authority Control in a Networked Environment," International Cataloguing and Bibliographic Control: Quarterly Bulletin of the IFLA UBCIM Programme 33, no. 4 (2004): 71-75.

140. Suzanne R. Graham and Dina DeCesare Ross, "Metadata and Authority Control in the Civil Rights in Mississippi Digital Archive," Journal of Internet Cataloging 6, no. 1 (2003): 33-42.

141. Martha Plettner, "Arabic Name Authority in the Online Environment: Options and Implications," International Cataloguing and Bibliographic Control: Quarterly Bulletin of the IFLA UBCIM Programme, 32, no. 2 (April/June 2003): $23-25$.

142. Ibid., 24.

143. Ia McIlwaine, ed., Knowledge Organization and the Global Information Society: Proceedings of the Eighth International ISKO Conference, 13-16 Jul. 2004. London, U.K. (Wurburg, Germany: Ergon Verlag, 2004).

144. Patton, "FRANAR: A Conceptual Model for Authority Data," 91-104.

145. Ibid., 97-100

146. Ibid., 102.
147. Marsha Starr Paiste, "Defining and Achieving Quality in Cataloging in Academic Libraries: A Literature Review," Library Collections, Acquisitions, \& Technical Service 27, no. 3 (2003): 327-38.

148. Ibid., 336.

149. Jeffrey Beall and Karen Kafadar, "The Effectiveness of Copy Cataloging at Eliminating Typographical Errors in Shared Bibliographic Records," Library Resources \& Technical Services 48, no. 2 (2004): 92-101.

150. Deborah E. Kulczak and Cathy Reineka, "Marcive GPO Records and Authority Control: An Evaluation of Name and Subject Headings at the University of Arkansas Libraries," Cataloging \& Classification Quarterly 38, no. 1 (2004): 87-103.

151. Hee-sook Shin, "Quality of Korean Cataloging Records in Shared Databases," Cataloging \& Classification Quarterly 36, no. 1 (2003): 55-90.

152. David W. Bade, Misinformation and Meaning in Library Catalogs (Chicago: D. W. Bade, 2003), 17.

153. David W. Bade, The Theory and Practice of Bibliographic Failure or Misinformation in the Information Society (City of the Red Hero: Chuluunbat, 2004).

154. Ibid., 220.

155. Ibid., 329.

156. Andrew MacEwan and Thurston Young, "Quality versus Quantity: Developing a Systematic Approach to a Perennial Problem," Catalog and Index 152 (Summer 2004): 1-7.

157. Ia McIlwaine, "Introduction," Subject Retrieval in a Networked Environment: Proceedings of the IFLA Satellite Meeting held in Dublin, Ohio, 14-16 Aug. 2001 and Sponsored by the IFLA Classification and Indexing Section, the IFLA Information Technology Section and OCLC (München: K. G. Saur, 2003), vii.

158. Gerhard J. A. Riesthuis, "Information Language and Multilingual Subject Access," in Subject Retrieval in a Networked Environment: Proceedings of the IFLA Satellite Meeting held in Dublin, Ohio, 14-16 Aug. 2001 and Sponsored by the IFLA Classification and Indexing Section, the IFLA Information Technology Section and OCLC, ed. Ia McIlwaine (München: K. G. Saur, 2003), 11-18.

159. Patricia S. Kuhr, "Putting the World Back Together: Mapping Multiple Vocabularies into a Single Thesaurus," in Subject Retrieval in a Networked Environment: Proceedings of the IFLA Satellite Meeting held in Dublin, Ohio, 14-16 Aug. 2001 and Sponsored by the IFLA Classification and Indexing Section, the IFLA Information Technology Section and OCLC, ed. Ia McIlwaine (München: K. G. Saur, 2003), 37-42.

160. Tony Olson, "Integrating LCSH and MeSH in Information Systems," in Subject Retrieval in a Networked Environment: Proceedings of the IFLA Satellite Meeting held in Dublin, Ohio, 14-16 Aug. 2001 and Sponsored by the IFLA Classification and Indexing Section, the IFLA Information Technology Section and OCLC, ed. Ia McIlwaine (München: K. G. Saur, 2003), 21-24.

161. Carol A. Bean and Rebecca Green, "Improving Subject Retrieval with Frame Representations," in Subject Retrieval in a Networked Environment: Proceedings of the IFLA Satellite Meeting held in Dublin, Ohio, 14-16 Aug. 2001 and 
Sponsored by the IFLA Classification and Indexing Section, the IFLA Information Technology Section and OCLC, ed. Ia McIlwaine (München: K. G. Saur, 2003), 114-21.

162. Genevieve Clavel-Merrin, "MACS (Multilingual Access to Subjects): A Virtual Authority File Across Languages," Cataloging \& Classification Quarterly 39, no. 1/2 (2004): 323-30.

163. Laurence S. Creider, "What Are Academic Libraries Doing with Spanish Language Subject Headings?" Journal of Academic Librarianship 29, no. 2 (2003): 88-94.

164. Alenka Šauperl, "Catalogers' Common Ground and Shared Knowledge," Journal of the American Society for Information Science and Technology 55, no. 1 (2004): 55-63.
165. Ibid., 62 .

166. Ed O'Neill and Lois Mai Chan, "FAST (Faceted Application of Subject Terminology): A Simplified LCSH-based Vocabulary," in Access Point Library: Media-Information-Culture: World Library and Information Congress: 69th IFLA General Conference and Council, Berlin, Germany, Aug. 1-9, 2003, www.ifla.org/IV/ifla69/papers/010e-ONeill_Mai-Chan.pdf (accessed Jul. 13, 2005).

167. Rebecca Dean, "FAST: Development of Simplified Headings for Metadata," Cataloging \& Classification Quarterly 39, no. 1/2 (2004): 331-52. 